\title{
Causative Structure of the Public Trust in the Banks
}

\author{
Marcin IDZIK \\ Warsaw University of Live Sciences, Poland \\ marcin_idzikesggw.pl
}

\begin{abstract}
The objective of this paper is to empirically explain how the trust in banks is influenced by the nominal, performative, altruistic and axiological factors in different age-groups of the consumers. The aim of this paper is to answer what factors influence the trust in banks. The structural equation model (SEM) was used in the empirical research to model how trust depends on the type of expectations that a customer has from a bank as well as the essence of the overall trust. The empirical database was comprised by the results of the surveys conducted by the author in the fourth quarter of 2016 on a representative nationwide sample of $\mathrm{N}=3000$ people aged 15 and over. The SEM estimating model yielded positive verification of the model hypothesis, according to which, the trust in banks is built by the normative, performative, altruistic and axiological determinants. The most important thing in building the trust in banks is the banks' proper response to the consumers' normative expectations that they have from the banks. Secondly, the axiological determinants are responsible for the trust in banks.
\end{abstract}

Keywords: Banks, Trust, Structural Equation Models (SEM).

\section{Introduction}

The Polish society has limited trust in different public institutions operating in Poland. However, from the list of almost 20 different public organizations, including those from outside the financial sector, banks are trusted by the public more than the judicial authorities, local authorities or the government or parliament [10]. When answering a question which only allowed for three answers, namely: "Yes," "No," or "Do not know, difficult to say," 70\% of the consumers aged 15 and over trusted banks that they used, $66 \%$ trusted the bank assistant who most frequently served the customer, 54\% trusted NBP (National Bank of Poland), and 50\% of the society trusted banks in Poland [9].

Trust and lack of trust in banks may be of selective character concentrated only on certain factors that form the trust in banks [10]. Every consumer has his/her own private balance of factors, on the basis of which, he/she builds or loses his/her trust in banks. On the other hand, every bank or every bank's assistant serving the customers has a number of people who trust them and those who do not trust them. Realizing that fact as well as the proportions of the different factors of building/losing trust in banks is also a significant element defining the proper relationship between the banks 
and the customers [17]. This is all the more important because if the bank betrays its trust, this is a destructive event for the customer [21], which can lead to the emergence and strengthening of the overall lack of trust 3, 10]. It may also entail spreading it to the different players on the banking market or even to the whole system [1]. However, the answer to the question concerning the factors that influence trust or its lack in banks in the different groups of customers is the key problem-to what extent the banks answer the normative, performative, axiological or altruistic expectations, and which of these categories play a key role for each generation that uses the banking services. These issues were, among others, touched upon by A. Giddens [5].

The issue of trust has become a necessary element in forming the relationships between banks and the different groups of stakeholders. However, there is no work conducted in order to adapt the sociological theories of trust to the specific characteristics of the market of the financial services. This paper in part fills this gap. In Poland, apart from the initial paper by the author, nobody has so far applied empirical verification of the theoretical models of trust and the SEM methodology for studying determinants of trust in banks. Such studies due to their complexity of subjects, interdisciplinary character as well as the high costs are not conducted in Poland apart from the ones discussed in this paper as well as in the papers of Idzik [9].

The objective of this paper is to answer the following questions: a) How do the customers define their trust in banks? b) Is the model of trust in banks based on the banks' institutional determinants adequate to the description of this phenomenon at present? c) What factors influence the trust in banks?

This paper touches upon the empirical explanation of the determinants of the customers' trust in banks and establishing the force and direction of the mutual influence in the different age groups of the consumers. Pursuing the development of the theory of trust [22] with the use of the SEM structural models, this paper conducted an empirical verification of the grade model of trust that was modified by the author.

The following elements, first of all, are in favor of applying the SEM models to analyze the determinants of the trust in banks in Poland, namely: (1) the need to verify and update the currently binding theoretical models, (2) the need to study more thoroughly the relationships and feedback between the theoretical constructs and their empirical arguments explaining trust, (3) the need to prove the causative role of the constitutional factors and unconscious factors in building trust, (4) the need to better control the sources of the change in the results which yields more accurate typologies of the people in terms of the certain factors influencing their trust in banks. Literature on these subjects underlines numerous advantages of applying these multidimensional statistical analyses. SEM allows one to verify the hypotheses concerning the occurrence of a specific structure of relationship among the variables $[16,19]$. 


\section{Research methods}

The analysis of the determinants of the trust in banks requires an approach which takes into consideration both the psychological model of this phenomenon as well as the empirical model. In the first case, on psychological grounds, the so-called grade model of trust was utilized. The Structural Equation Modelling (SEM) was used for the empirical description of the causative relationships taking into account the psychological factors. In terms of the diverse level of trust in banks, the typological groups of consumers were selected using the method of the CHAID classification tree (Chi-squared Automatic Interaction Detector). The empirical research was conducted as part of the "Retail Banking Audit" project financed by TNS Polska. The empirical database was comprised by the results of the surveys conducted by the author in the fourth quarter of 2016 on a representative nationwide sample of $\mathrm{N}=3000$ people aged 15 and over, including $\mathrm{N}=2328$ people who were the individual customers of banks.

\subsection{Theoretical Model of Trust}

Sztompka [22] defines trust and its lack as "betting on the future and uncertain activities of other people." The use of the word "betting" in this definition indicates that trust is not only a passive hope, but it also implies certain activity-making a decision which carries a certain amount of risk. The most frequent characteristics of trust are honesty (acting in good will, telling the truth, keeping one's promises), kindness (care and acting for the good of the other party), competence (skills necessary in a given situation), and predictability (consistent actions). Trust is also one of the key customer expectations of banks. In the context of trust Sztompka [22] selected three categories of expectations: performative, axiological and care-taking. In this light, the trust in banks is gradationally diversified depending on the type of the expectations from banks. The discussed grade model of trust originates from categorizing the customers' expectations from the providers of different types of services. The concept of Sztompka was additionally expanded by the author of this paper by adding a superior category of expectations, the so-called, normative expectations. Each area of expectations was described by statistical indexes adequate for the banking market in Poland.

When interacting with the bank, the consumers may make more radical or cautious decisions, take higher or lower risk. Trust is grade diversified depending on the type of expectations from the partners of interaction within the banking system [8].

The normative stability is a response to the normative expectations from the banks. This layer of the determinants of the trust refers to the rules upheld in the banking system. If these rules are well articulated, consistent, transparent and legitimate, a feeling of order, predictability, regularity and security emerges. This alone is sufficient for the emergence of an instrumental type of trust in an institution as such. Throughout the ages, such sayings emerged in the social awareness "pewne jak w banku" (literally: "certain as a bank") or "masz to jak w banku" (literally: "sure as a bank"). This statement is the best exemplification of the normative determinants of the trust in banks [9]. 
The performative expectations concern the instrumental properties of the actions undertaken by the banks. This is the answer to the expectations that the activities of the banks will be regular, proper and predictable. The expectations of the competence, efficiency, effectiveness or productivity are already slightly higher. All these cases, however, involve certain formal properties of the activities undertaken by the banks, excluding the deeper semantic layer of these activities. It can be said that the expectations of this type are connected with the trust in the organizational aspect of the functioning of the banks and the whole banking system.

The axiological expectations concern special humanistic properties of the banks' activities. When placing this kind of trust in a bank, a consumer expects that the bank will act responsibly, justly, fairly, strictly by the book, veraciously, etc. This kind of expectations is connected with the trust in the ethical sphere of the functioning of the bank and its representatives.

The fourth category includes care-taking expectations connected with such activities where the consumers count that the bank will be selflessly taking care of their matters, that it will be altruistic and that it will provide support. Such expectations are the components of trust in the area of the functioning of banks which is mythologized by the social consciousness which implies that the underlying principle of the banks' functioning is a definition that "a bank is an institution of public trust; therefore, its superior objective is public interest."

\subsection{Structural Equation Modelling SEM}

The SEM models allow one to conduct a multidimensional and multi-variable analysis of the empirical data and offer much higher opportunities than those provided by classic statistics. The assumtions of the SEM structural models were developed by, among others $[1,4,12,14,15,16,18,20]$.

Structural Equation Modeling (SEM) is a set of procedures of multidimensional statistical analyses which in a classic approach are based on the general linear model. The structural models emerged from the two main techniques: the confirmatory factor analysis [6] and multidimensional regression and path analyses [7]. SEM is a technique of testing and evaluating the causative relationships using the empirical data and qualitative causative assumptions.

The structural models test the linear results of the latent exogenic variables (independent and explanatory) in the scope of the other latent endogenic variables (dependent and explained). Each of the latent variables is measured by an assigned set of measurable empirical variables. The structural models enable one to study at the same time the influence of many sources on the dependent variable [14]. An unquestionable advantage of SEM is the possibility to analyze both direct and indirect relationships. Moreover, the variables included in the models can be measured on different scales [12]. 


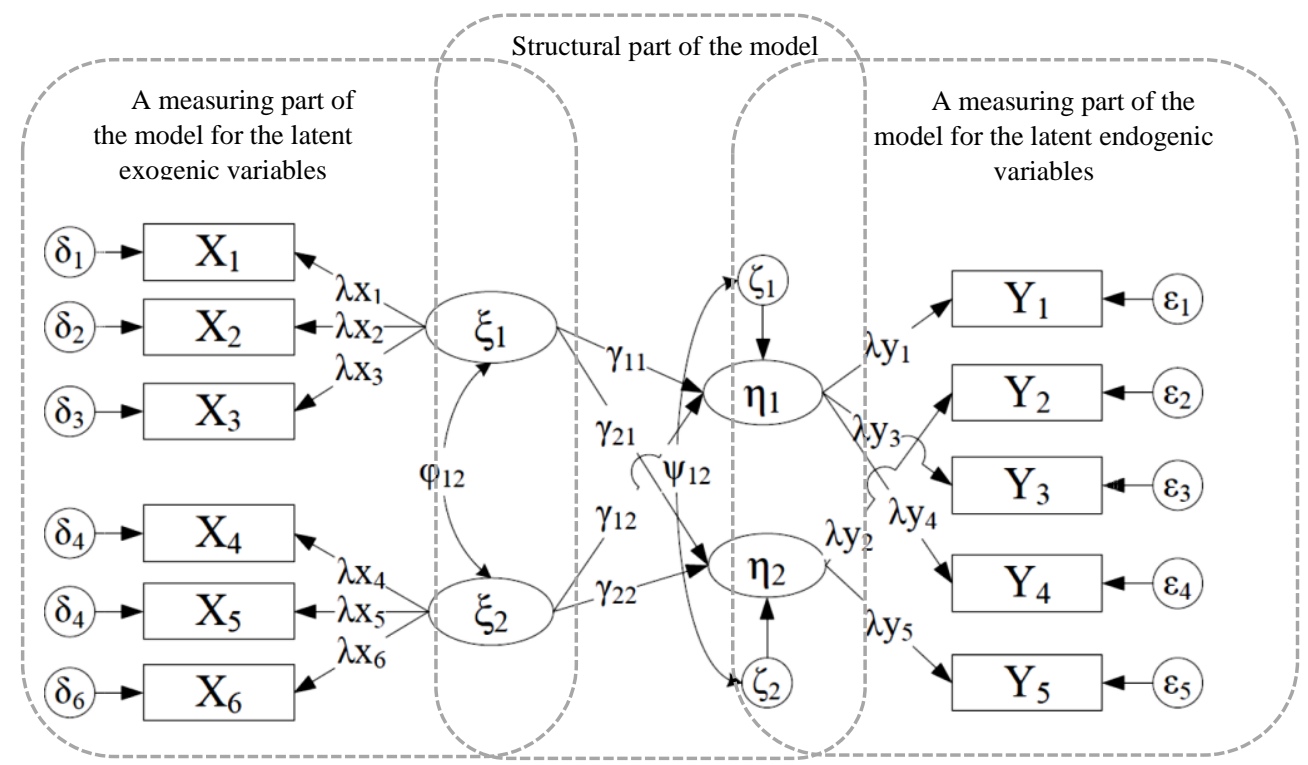

Fig. 1. Schematic of a hypothetical causative model of the structural equation modelling SEM with the unobserved variables [11].

\section{SEM notation [11]:}

- Notations for the latent model:

$-\xi_{i}$ - latent exogtenic variables (factors),

$-\eta_{i}$ - latent endogenic variables (factors),

$-\zeta_{i}$ - in equations, errors connected with the latent endogenic variables,

$-\gamma_{i j}$ - a coefficient referring to the influence of $\xi_{i}$ on $\eta_{i}$ (direct effect),

$-\varphi_{i j}$ - covariations among the latent exogenic variables $\bar{\xi}_{i}$,

$-\psi_{i j}$ - covariations among the $\zeta_{i}$ errors connected with the measurement of the $\eta_{i}$ variables.

- Notations for the measurement model:

$-Y_{i}$ - observed indexes for $\eta_{i}$

$-X_{i}$ - observed indexes for $\xi_{i}$,

$-\varepsilon_{i}-$ an error connected with the measurement of a specific $Y_{i}$ index,

$-\delta_{i}$ - an error connected with the measurement of a specific $X_{i}$ index,

$-\lambda y_{i}-$ a coefficient referring to the influence of $\eta_{\mathrm{i}}$ on $Y_{i}$,

$-\lambda x_{i}-$ a coefficient referring to the influence of $\xi_{i}$ on $X_{i}$.

The model (Fig. 1) is comprised of an internal model describing connections between the latent variables and an external model which studies unobserved endogenic and exogenic variables [2]. The external model represents the results of the factor analysis that allows one to calculate the loading of each factor influencing the latent variable. The internal model presents a path analysis that allows one to determine the causeeffect relationships among the variables. The structural part of this model enables one 
to test the basic research hypothesis, in other words, a hypothesis about the lack of the formal basis for rejecting the proposed theoretical model if the traditional measure which is the result obtained in the $c h i_{2}$ test does not exceed the critical distribution value $\left(c h i_{2} ; p>0.05\right)$. In this situation, the result of the $\mathrm{H}_{0}$ verification serves as a basis to accept or reject the research hypothesis about the acceptability of the causative influence of the psychological reality represented by the latent exogenic variables on the reality represented by the latent endogenic variables.

Prior to verifying the main hypothesis, submodels are being prepared in order to verify the detailed hypotheses, for example, concerning the acceptability of the specific theoretical construct $\left(\xi_{i}\right.$, or $\left.\eta_{i}\right)$ which reflects a given cognitive construct. In order to do this, a confirmatory factor analysis is used. For example, if one wants to test the influence of two exogenic variables $\left(\xi_{1}\right.$ and $\left.\xi_{2}\right)$ on an endogenic variable $\left(\eta_{1}\right)$, then $X_{1,2,3}$ are the observed indexes for $\xi_{1}$, and $X_{4,5,6}$ are the observed indexes for $\xi_{2}$. These indexes constitute research material arranged in an empirical data matrix $(S)$. Similarly in the case of the endogenic construct of $\eta_{l}$, these are the observed indexes: $Y_{1,2,3,4,5}$. The matrix is a basis for testing, in other words, proving the acceptability of the theoretical model $(\Sigma)$ if the value in the $c h i_{2}$ test is not significant (i.e., $p>0.05$ ) in the result of the conducted estimation. However, before we test the accessibility of the most important hypothesis about the significant influence of the exogenic variables on the endogenic variable, the partial models (submodels) are being verified [11].

The interpretation of the standardized estimates for the paths is of key cognitive value: if the value of the variable, from where an arrow originates, increases by 1 standard deviation, then the value of the variable, where the arrow is going, will increase by the estimated value of the path coefficient (a standard regression weight) if the sign of this coefficient is positive [15]. The result of the performed estimation of the model yields information about the values of the squared multiple correlation coefficient, which appear with the endogenic variables both latent $\left(\eta_{i}\right)$, as well as observed $Y_{\mathrm{i}}$ - indexes for $\eta_{i}$ and $X_{i}$ - indexes for $\xi_{i}$. Each of these pieces of information is described by the percentage (if the calculated estimated value is multiplied by 100) to which a given variable is explained by the influence of those variables which send arrows towards it. It is worth mentioning that the variables sending arrows are the predicators for the variables which receive arrows. If the causal model does not take into consideration the role of the mediator for the latent endogenic variable $\left(\eta_{1}\right.$ or $\left.\eta_{2}\right)$, and in such a way controls only the most important direct influences (e.g., $\gamma_{11}$ represents an influence between $\xi_{1}$ and $\eta_{1}$ ) and gives up the control of the direct influences $\left(\beta_{21}\right.$ or $\left.\beta_{12}\right)$ between the endogenic variables, then a correlation $\left(\psi_{12}\right)$ between the measurement errors $\left(\zeta_{1}\right.$ and $\left.\zeta_{2}\right)$ of the latent endogenic variables should be allowed at the stage of the model specification. It is assumed that the source of the variability $\eta_{1}$ and $\eta_{2}$ may be explained not only by the influence of the exogenic variables $\left(\xi_{1}\right.$ and $\xi_{2}$ ), but also by the other exogenic variables which have not been included in the model [6]. 


\section{Determinants of trust in banks from the perspective of the SEM model}

The trust analysis may be started with the statement that trust is not one variable, as it has been assumed so far in banking. The security of the money explains slightly more than $40 \%$ of the phenomenon of trusting banks. The definition of trust in banks based on security is incomplete and inadequate for the society's expectations from banks $[10,21]$. Additional confirmation of this thesis can be found in the results of the empirical survey. A confirmatory factor analysis was performed for the whole sample. As a result, we arrived at four main groups of the determinants of the trust in banks, that is to say, normative, performative, axiological and altruistic. However, in the course of the further analysis and because of the need to obtain a complete picture of the relationships forming the trust in banks, another confirmatory factor analysis was conducted in order to identify the consistent constructs such as: the price, the availability, the offer, the customer service (within the scope of the performative determinants as well as the relationships with the customers), the communication of the banks, and the ethical conduct (within the scope of the axiological determinants). Eventually in the model there were 11 latent variables (unobserved directly).

Table 1. Selected measures of quality of the measurement models of the latent variables.

\begin{tabular}{lcccc}
\hline Latent variable & $\begin{array}{l}\text { Average } \\
\text { Variance } \\
\text { Extracted }\end{array}$ & $\begin{array}{l}\text { Composite } \\
\text { Reliability }\end{array}$ & $\mathbf{R}^{\mathbf{2}}$ & $\begin{array}{l}\text { Cronbachs } \\
\text { Alpha }\end{array}$ \\
\hline Normative determinants & 0.831 & 0.908 & 0.450 & 0.797 \\
Performative determinants & 0.436 & 0.902 & 1.000 & 0.881 \\
Axiological determinants & 0.532 & 0.953 & 1.000 & 0.947 \\
Altruistic determinants & 0.764 & 0.907 & 0.549 & 0.846 \\
Price & 0.821 & 0.902 & 0.655 & 0.783 \\
Availability & 0.810 & 0.895 & 0.732 & 0.765 \\
Ethical conduct & 0.717 & 0.910 & 0.895 & 0.869 \\
Communication & 0.647 & 0.916 & 0.620 & 0.890 \\
Customer service & 0.645 & 0.879 & 0.543 & 0.816 \\
Product offer & 0.624 & 0.868 & 0.542 & 0.798 \\
Customer relations & 0.633 & 0.896 & 0.425 & 0.855 \\
\hline
\end{tabular}

Each of the nine models measuring the latent variables included in the structural model (Fig. 2) were separately evaluated by using a univariate confirmatory factor analysis. The measures of fitting the measurement models for the data are collected in Table 1. One of the basic measures of the quality of the latent variables is the Average Variance Extracted. This is a part of the variance of the measurable variables that make up a given latent variable reconstructed by this latent variable. Average Variance Extracted in the majority of the cases exceeds 0.5 with an exception of 
a variable building the category of performative determinants. The Composite Reliability measure shows what part of the variance of the measurable variables is recreated by the latent variable created by them. In each case, its value is over 0.85 which, given the critical value of 0.7 , reveals the proper reproduction of the measurable variables on the latent structure of the model. Also in the case of all the factors the value of the Alfa-Cronbach [2] coefficient exceeded 0.75 which testifies to the high reliability of the applied measuring scales.

After specifying, the model was estimated by the method of the highest reliability. The reliability of the received results was tested using procedures of "Bootstrap" resampling, where the analysis is conducted repeatedly on subsets drawn from a base sample, and the results of this analysis are averaged. Thanks to them the evaluation of the standard error of the parameters and the Student's t-distribution values were obtained. As a result we arrived at the parameters of the model with standard errors and $\mathrm{t}$-distribution, value $\mathrm{R} 2$ for each of the variable and several measures of the quality of the model as well as standardized values of the latent variables (Table 1). All the relationships in the model are significant on the level of relationships on the level of $\mathrm{p}<0.001$.

In the estimated SEM model of the trust in banks we can discern an internal path structure which describes the cause-effect relationships as well as ten measuring models which characterize the relationships between the latent variables and their observed indexes. On Figure 2, the measurable variables in the measuring models are marked by rectangles. The number of rectangles testifies to the number of the measurable variables building a given latent variable. In the overall perspective, the following elements are of key importance in creating trust, namely, normative determinants (the total effect of 0.538 ), then axiological determinants (the total effect of 0.503 ), ethical conduct (the total effect of 0.451 ), performative determinants (the total effect of 0.224), bank communication (the total effect of 0.201), relations with the customers (the total effect of 0.145), axiological determinants (the total effect of 0.109), customer service at the banks (the total effect of 0.091), product offer (the total effect of 0.087 ), availability of the banks (the total effect of 0.048 ) and the prices of the banking services (the total effect of 0.045). The total effect presents a combined influence of the given factors on the trust in banks. This is a sum of the direct influence, but also of the indirect influence through the different categories of evaluation of the banks. For example, the ethical conduct influences the evaluation of the axiological determinants (the path coefficient is 0.254 ), but also its influence on the evaluation of the axiological determinants is directly executed through the relations with the customers. Similarly, the axiological determinants directly influence the trust (the path coefficient is 0.411), but the total influence of the axiological determinants on the trust is effected also indirectly through the evaluation of the normative determinants. Thus a direct influence of the normative determinants on the trust described with a path coefficient is 0.411 , but the total effect is already 0.503 . 


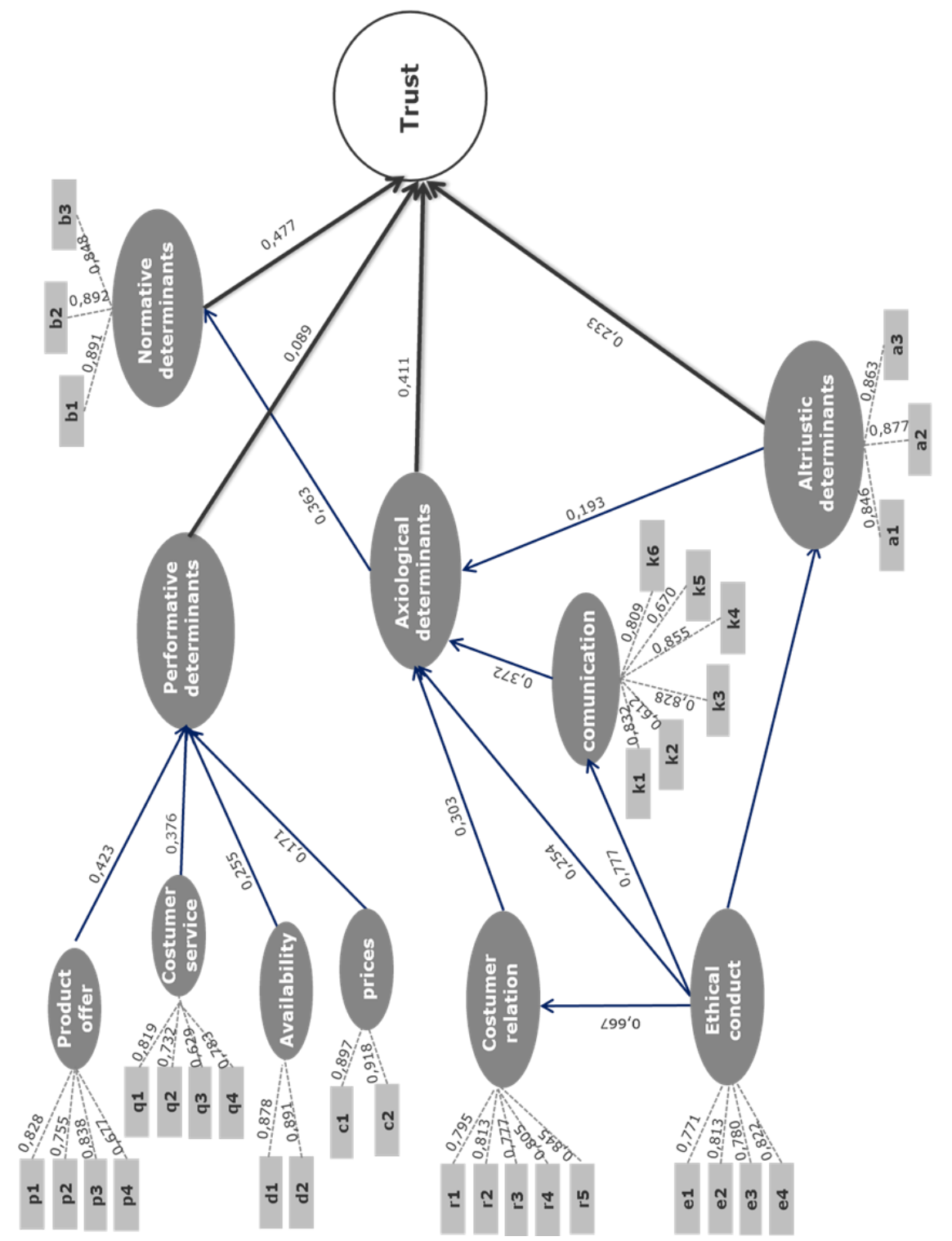

Fig. 2. A diagram of the general SEM structural model of the trust in banks with the standardized values of path coefficients and factor loadings.

\section{Summary}

The structural equation modelling (SEM) allowed us to conduct a theoretical grade model of trust in banks. The SEM estimating model allowed us to positively verify 
the model hypothesis, according to which, the trust in banks is built by the normative, performative, altruistic and axiological determinants.

It was proven that the traditional definition of the trust in banks that refers to the security and the functioning of a bank as an institution explains the phenomenon of trusting banks only to a small extent. The analyses should include a broader range of factors - apart from security, also daily experiences of the customers with banks, evaluation of the offer, availability, costs of the services, quality of the services as well as a very important aspect of the ethical evaluation of the banks, their communication, as well as observing the norms which is not simply following a code of good practices.

The most important thing in building the trust in banks is the banks' proper response to the consumers' normative expectations that they have from the banks. Secondly, the axiological determinants are responsible for the trust in banks. These are followed by the performative determinants.

\section{References}

1. Coleman, J. C.: Foundations of Social Theory. 1st edn. Harvard University Press, Cambridge (1990).

2. Cronbach, L. J.: Coefficient alpha and the internal structure of tests. Psychometrika, 16(3), 297-334 (1951), DOI: 10.1007/bf02310555.

3. Gambetta, D.: Trust - Making and Breaking Cooperative Relations. 1st edn. Basil Blackwell Ltd., Oxford (1988).

4. Gatnar, E.: Statystyczne modele struktury przyczynowej zjawisk ekonomicznych. 1st edn. Akademia Ekonomiczna Katowice, Katowice (2003).

5. Giddens, A.: Nowoczesność i tożsamość. 1st edn. Warsaw, Wydawnictwo Naukowe PWN, (2002).

6. Harrington, D.: Confirmatory Factor Analysis. 1st edn. Oxford University Press, Oxford (2008).

7. Hollander, M., Wolfe, D.: Nonparametric statistical methods. Wiley series in probability and statistics: applied probability and statistic. 2nd edn. Wiley, New York (1999).

8. Idzik, M., Gutkowska, A.: Czy klientów stać na dobry produkt, http://docplayer.pl/2474897-Czy-klientow-stac-na-dobry-produkt.html, last accessed 201711-26.

9. TNS Polska: Materiały konferencyjne 2014.

10. Idzik, M.: W poszukiwaniu zaufania. Kurier Finansowy 2(28), 22-25 (2012).

11. Idzik, M.: Zaufanie do wybranych instytucji sektora finansowego. Materiał z konferencji prasowej KNF z dn. 16.04.2012 (2012).

12. Januszewski, A.: Modele równań strukturalnych w metodologii badań psychologicznych. Problematyka przyczynowości w modelach strukturalnych i dopuszczalność modeli. Studia z psychologii w KUL. T. 17, 213-245 (2011).

13. Jöreskog, K. G.: Structural Equation Modeling with Ordinal Variables Using LISREL, http://www.ssicentral.com/lisrel/techdocs/ordinal.pdf, last accessed 2017-11-26.

14. Kaplan, D.: Structural Equation Modeling: Foundations and Extensions. 1st edn. Sage Publications, California (2000).

15. Kline, R. B..: Principles and practice of structural equation modeling. 3rd edn. The Guilford Press, New York (2011). 
16. Konarski R.: Modele równań strukturalnych. Teoria i praktyka. 1st edn. Wydawnictwo Naukowe PWN, Warsaw (2010).

17. Korol, J.: Modele równań strukturalnych i sieci neuronowe w modelowaniu rozwoju zrównoważonego. 1st edn. AWE Akademickie Wydawnictwo Ekonomiczne, Gorzów Wielkopolski (2005).

18. Lewicka-Strzałecka, A.: Zaufanie w relacji konsument-biznes. Prakseologia 143(1), 195207 (2003)

19. Osińska M.: Ekonometryczna analiza zależności przyczynowych. 1 st edn. Wydawnictwo Naukowe Uniwersytetu Mikołaja Kopernika, Toruń (2008).

20. Patterson R.: Kompendium terminów z zakresu finansów po polsku i angielsku. 1 st edn. Wydawnictwa Akademickie i Profesjonalne, Warsaw (2002).

21. Pearl J.: Causality. Models, reasoning and inference. 2nd edn. Cambridge university press, Cambridge, (2000).

22. Seligman A.: The Problem of Trust. 1st edn. Princeton University Press, Princeton (1997).

23. Sztompka P.: Zaufanie, Fundament społeczeństwa. 1st edn. Znak, Kraków, (2007). 